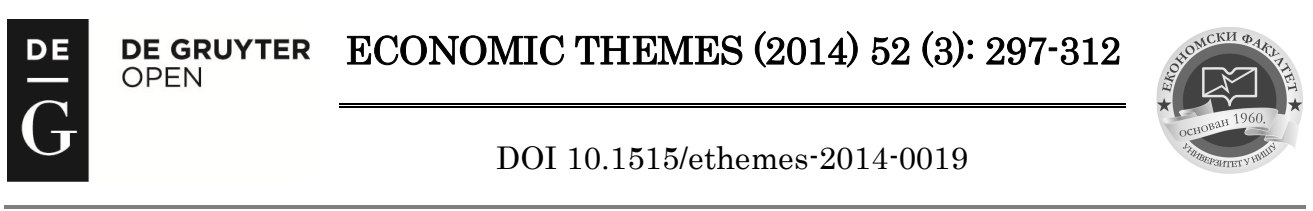

\title{
INDUSTRIAL POLICY AS THE EUROPEAN UNION COMPETITIVENESS FACTOR ON THE GLOBAL MARKET
}

\author{
Gorica Bošković \\ University of Niš, Faculty of Economics, Serbia \\ $\bowtie$ gorica.boskovic@eknfak.ni.ac.rs \\ Ana Stojković \\ PhD student, University of Niš, Faculty of Economics, Serbia \\ $\bowtie$ anastojkovic73@yahoo.com
}

UDC

338.45

(4-672EU)

Review paper

Received:

29.08.2014.

Accepted:

24.10.2014.
Abstract: The union of the most developed European countries and their heavy industry based economies after the World War II, seemed like the only answer to USA's and Japan's powerful economies. At the same time, it was the only chance for Europe to become competitive in the global market. That was achieved through various forms of economic communities, formed in Europe in the second half of XX century. Since the 1992. Maastricht Treaty, they are known as the European Union. European Union industrial policy had the same priorities since the very beginning - to make Europe the leader of global economy, through investments in knowledge and high-tech inovation. However, that still hasn't happened and considering all the economical and political crisis shaking the Union lately, chances are it can hardly happen at all. Reasons are numerous and different, both inside and outside the Union. The implicit question being posed here is have the most developed world countries and their economies reached their peak and can the EU achieve further growth on the supersaturated global market? This paper investigates the role of industrial policy as one of the key factors for solution to many problems in the past as well as in the future of the EU, which would make this economic and political community of European countries much more competitive on the global market.

Key words: industrial policy, EuropeanUnion, competitiveness, global market, economic-political crisis. 


\section{Introduction}

The European Union (EU), which exists today as a unique economic and political community of 28 member states (which cover most of the European continent area), has its roots in the first decades after World War II (European Union, How the EU works, 2013). The idea of warworn European countries was to build a form of economic cooperation and thus restore their national economies, prevent possible renewed conflicts among themselves and protect the Union from the worldwide competition. In the decades that followed, the USA and Japan turned out to be the most dangerous competition for European economies, during the second half of the $20^{\text {th }}$ century. As a war winner, the USA based its powerful economy on mass production and had no significant competitors during that period. Japan on the other hand, as one of the biggest war losers, which was pulled down to the ground, with fanatic dedication and help from American engineers and consultants, rapidly became a superpower nation in the global economy.

All of the above resulted in signing of the Treaty of Parisin in 1951, which established the European Coal and Steel Community, for a period of 50 years. This community was supposed to be the first step towards the European Union and also to eliminate every possibility for possible further conflicts between member states, by merging their heavy industries. This also represented the intention of European countries to defend their economy from the worldwide competition (European Union, The Schuman Declaration, 2014). The same six states that have established the European Coal and Steel Community (West Germany, France, Italy, Belgium, The Netherlands and Luxembourg), signed another agreement in Rome in 1957, which established the European Atomic Energy Community and the European Economic Community. The Treaty of Rome basically shared the jurisdiction between the most influential states regarding larger industry investment. Their goal was to increase competitiveness of the European industry, in order to raise the Community performance efficiency, both in the internal market, as well as in the global one. The 1992 Maastricht Treaty established the European Union, based on the structure of former European communities.

The European Union designed the Lisbon Strategy in 2000 (also known as the Lisbon Agenda) - a new concept of industrial policy, which was supposed to make EU the most competitive economy in the world by 2010. Although some researches indicated positive trends of certain aspects in the Lisbon Strategy (like for example 1,8\% GDP growth and 1,5\% employment growth in 2002.), there were also estimates pointing out high costs regarding many unrealized goals of this strategy, particularly the growth of a potential gap. This gap was noticeable between the member states, as well as between the Union and its foreign trade partners (Council of the European Union, 2005). 
Europe 2020 was a new strategy, as a required consequence of the longest and hardest crisis in the history of the European Union, since its beginning. The 2008 economic crises created domino effect caused by the collapse of some biggest US investment banks, which additionally intensified accumulated problems of European economy.

Europe urgently needs a sustainable development strategy, coordinated with the industrial policy. The development and competitiveness of the Eropean Union on the global market is largely determined by industry development in the member states. In this respect, industrial policy represents significant factor of EU competitiveness on the global market.

\section{European Union Industrial Policy and the Global Market}

Establishment of economic communities in Europe in the second half of the 20th century created the need to define regulations, laws, procedures, both national and supranational, which were supposed to lay the groundwork for these communities. The European Union industrial policy, as an aspect of its economic policy, represented all the activities whose goal was to improve production within various industries, through constant inovation, for the purpose of conquering the most profitable market segments.

The development of the European Union's industrial policy was very complex and had to be carried out in phases and layers. In the very beginning the founding member states put the emphasis on state protectionism and heavy industry investment, in order to achieve global competitiveness (which was very difficult after World War II). Frequent disagreements regarding this problem between member states has led to the situation where common industrial policy of the Union mostly resulted in "...summary of industrial policies of member states. Such industrial policy had "sterile" horizontal effect, in accordance with conventional wisdom that industry's dominant position would be lost with its deindustrialization" ( Savić, 2013, p. 203). In time, as the number of the Union member states grew, it became clear that the internal market needs to “...facilitate structural transformation of traditional industry, set the environment for small and medium business and improve overall conditions for research, innovation and technological development" (Savić, 2013, str. 205). Small and medium-sized enterprises, especially the ones globally oriented and dedicated to continuous innovation, represent the main driving force in many European countries. With national and supranational incentives in forms of research and development funds, small and medium-sized enterprises greatly contribute in national income of those countries. However, harmonization and coordination of industrial policies is a highly complex process, and reasons for this are different apprehensions of the market among the most influental member states, their economic and political tradition and their relation with market and the way 
they choose to perform on it: "In France, ever since Jean-Baptiste Colbert, there is a long tradition of centralized economy management. Some Mediterranean countries have similar approach to this matter. Great Britain, ever since Margaret Thatcher, has been following almost completely classic liberal economic course. In German theory, as well as in political system, Ludwig Erhard has been the role model, with his concept of social market economy" (Vajdenfeld and Vesels, 2003, p. 157).

Although different countries had different visions of the Union market, they all agreed on creating common market of commodities, capital, human resources, information, new technologies. The idea was to form a supranational industrial policy, whose main goal would be balancing of national policies and coordination of mutual actions within the EU and its institutions. Another issue that should have been taken into account was a sustainable development - a phrase which arised at the end of the $20^{\text {th }}$ century, became one of the most important guidelines in the overall development of all stakeholders, as well as countries and their economic policies. It was a result of many negative consequences of high-tech development, that have endangered the survival of the world we live in. Global warming, intense exploitation of non-renewable energy sources, massive and continuous pollution of the planet, ruthless and endless race for profit on the global market, are some of these consequences. This fact had to be revised with a shift in economic strategy, which included significant involvement of environmental standards and other instruments of sustainable development in the European Union's industrial policy. Therefore, in its new regulations regarding further development in the new millennium, the Union had to pay much more attention to sustainable development, based not only on economic, but also on environmental postulates. One of the most important goals of industrial, as well as overall economic policy in the EU is to create the environment which would promote an open, mutual market and encourage competition among all participants. This can be achieved through continuous innovation development, as a result of research and development of industry in general.

Many authors have dealt with the topic of the industrial policy in the European Union. Regardless of different sources and interpretations, opinion that has prevailed is that development phases of industrial policy mostly concure with ones of the EU development, which were largely shaped by global developments of that period. Period after World War II is considered to be the first phase of the European industrial policy creation. As already stated, this phase brought certain forms of integration and cooperation of European states. The goal of these efforts was to restore their war worn national economies and the most significat result of those activities were already mentioned in the Treaty of Paris from 1951 and the Treaty of Rome from 1957. Numerous researches of this area consider this period to be one of most important periods, 
not only in the EU industrial policy development, but also one of the most important periods of the Union itself, with consequences that affected global economic and political scene.

After the creation of European communities in the 1950s, a certain type of foundation for the integration of European countries has been set and the 1960s brought an intense growth and development of European economies, especially of the founding member states. It seemed that the plan to defend themselves from their biggest competitors (USA and Japan) with certain forms of cooperation was going to work, which meant a place on the significant segments of the global market for the most productive of them. The 1960s were known as the Golden age of European economy. Intense economic development in many European countries also enabled progress of other important aspects of life, such as culture, science, human rights, freedom of speech and media etc. Occurrence that contributed most to this kind of progress was, without a doubt, a powerful development and transfer of new technologies. It was a result of large investment in the field of research and development by newly founded European communities. On the other hand, it was a direct effect of the US economy investment in European plants, in order of conquesting that important segment of global market (Cornet, 2009). Most of the income per capita in Europe was a result of investment and innovation in industry, with particularly significant structural change and migration of labor from the non-industrial to industrial sector. At the same time, a higher level of education among population resulted in intense growth of productivity and efficiency in the European industry. Consequences of this kind of economic growth in Europe were infrastructure, transportation and trade development in the mutual market, which resulted in record low prices of energy. All of the above led to a faster growth of income per capita, and the biggest economic growth among European countries in the 1960s was achieved in the Netherlands, Sweden, Italy, Spain etc. (Gales et al, 2007).

As it usually happens in economics and its cyclical trends, after an intense overall progress in the 1960s, the 1970s brought global crisis in the form of oil prices shock, caused by embargo of Arabian countries, the world's biggest oil manufacturers. In 1973, after the military intervention of Egypt and Syria in Israel and the US' support to Israel in weapons supply, some Arabian countries have imposed an oil embargo to Canada, Japan, The Netherlands, Great Britain and the USA. As a result of that action, the oil price jumped from 3 to 12 USD a barrel, since October 1973 till March 1974 (Yergin, 2008). That further led to stock market crash in 1973-1974, which was the biggest stroke for global economics since the Great Depression in the 1920s. This shock inevitably brought heavy consequences for European economics and its growth, which has been stopped for the first time after World War II. Stagnation and negative trends were particularly apparent in Eastern and Central Europe. The whole 
system of command economy and central planning collapsed and that was a serious hit for authoritarian political structures in these countries (Eichengreen, 2006). Another chain effect recession spread globally, causing a purchasing power decline even in the most developed countries, with global market which could no longer absorb all of the products manufactured worldwide. It was a beginning of the end of central planning production for some European countries, which based their economies on that idea after World War II. The solution which appeared instead was a direct consequence of that particular period and following ongoings on the global market. The time has come for neoliberalism, or neoliberal capitalism, which still exists nowadays in certain modified forms.

Second half of the 1970s and the beginning of the 1980s brought efforts of not only European countries, but also other countries worldwide, to restore their economies, after the oil shock collapse. "Between mid 1960s and the 1970s, an industrial structure has been made within mutual internal market, with industrial policy strategic goal to focus on organization, restructuring of companies and high-tech development. Period of early 1980s was a period of defense industrial policy and after crisis restructuring, and in 1987 industrial policy begins hightech industry promotion" (Sauter, 1997, pp. 75-79).

However, just like after World War II, European countries had to accept the fact that the high-tech leaders on the global market were still the USA and Japan, but also some countries from Southeast Asia. These countries exploded economically during last decades of the 20th century and became fierce competition on the global market, which required a continuous benchmarking and some emergency measures in the EU industrial policy. One of those measures was a shift from strict national interest orientation to a precise and coordinated supranational industrial policy strategy within mutual market. First step in this modern European industrial policy was a commitment to research and development of new technologies in order to improve a high-tech industry, which was an absolute priority of industrial policy new strategy. Furthermore, orientation to new high-tech developments in European industry became a key element of active industrial policy of the EU, and that strategy was confirmed with Maastricht and Lisbon Treaties, which are considered to be the foundation of the EU functioning policy. The Maastricht Treaty from 1992 establishes the industrial policy area, as one of the six new most important areas for the European Union in the future (Summaries of EU Legislation, 2010). It was a beginning of the initiative in the Union, as well as among the state members in order to raise competitiveness of the European industry on the global market. This initiative meant to apply all the activities which could boost competitiveness through significant structural changes of the European economy, especially towards world leading economies, USA and Japan. The goal was to create the base for integration and network of large corporations, 
state owned and private companies in the internal EU market. That kind of combination of financial power, educated workforce and continuous high-tech application could compete with global economy leaders, who have already taken the most profitable segments of global market (Devine et al, 1996). On the other hand, the Union had to constantly improve working environment for small and medium-sized business, especially the ones with inovative orientation and globally competitive. These companies are considered to be the economy foundation in many European countries, as they generate a significant part of their income.

A very obvious shift from sector (measures designed for traditional industry restructuring - production of steel, textile, shipbuilding, automotive industry, all of which were suffering severe competition from USA and Japan and their hightech products) to a much more complex horizontal development, ${ }^{l}$ in accordance with other different policies, was an introduction in procreation of most important strategy in the history of European Union (not only in industrial policy area, but also all the other aspects of its existance) - The Lisbon Strategy.

\section{The Lisbon Strategy - Industrial Policy Concept for Fostering Competitiveness of the European Union}

New millennium continued with fierce competition on the global market, which allowed survival only to most powerful, adaptable and prepaired players, ready to adjust to everyday changes of contemporary business instantly. Creation of the EU's industrial policy new strategy was supposed to be the answer to economic and political domination of the USA, constant inovation of the Japanese industry, intense development of China into a new global economy leader, but also some other countries development worldwide (Brazil, Azerbaijan, Singapore, Mozambique). By then it became clear that the weakening of the EU competitiveness was caused by a fundamental mistake policy creators have been focusing less on a strong industry maintenance, and more on the services sector, which was considered to be a base of modern economy. New strategy program set industry development as a foundation of sustainable (economic, social and environmental) EU development, in the Lisbon European Council summit in 2000. Main tasks of this strategy were establishing stable growth of all economic performances, higher employment rate, continuous researh and development, innovation and education, and particularly constant implementation of sustainable developmet and CSR. (IvanUngureanu and Marcu, 2006). According to this strategy, these goals were

\footnotetext{
${ }^{1}$ Implementation of horizontal industrial policy "should create space for other policies and their actions, which would improve competitiveness of the EU, because their instruments often match (competition, internal market, research and development, education, policy of exchange and sustainable development)" (Savić, 2013, p.223).
} 
supposed to be realized by 2010 . However, after only few years it was obvious that the implementation of the Lisbon strategy wasn't going according to plan non of the strategy areas has achieved planned results. ${ }^{2}$

New rules of global economic and political scene required adjustments in the industrial policy activities according to social and environmental rules of sustainable development concept, while minding manufacturing needs at the same time. Concurrently, there is opinion about high-tech society (where consumers and their preference rule among many available high-tech products), depending on services based on knowledge and human resource key competence, rather than manufactoring sector, within the EU, as well as globally. The economic structure of European countries has clearly shifted from traditional economic sectors, such as agriculture and industry, towards services. Some authors believe that this process was largely influenced by outsourcing phenomenon. It practically meant that activities which were done ,at home“ before, have now been assigned to manufacturers "from the outside“. Outsourcing has both internal and international significance. Internally, some of the activities that were being done independently by the companies, such as transport, logistics, accounting, are now done by other companies as services. However, an international aspect is also significant - domestic company transfers a part of its manufacturing process to a company in a foreign country, because of much lower human labour cost than in resident country. Besides cost reduction, companies from developed countries try to conquer most significant segments of foreign markets. Such structural changes resulted in 3,2\% decrease of industry share in total gross added value in the EU-27 between 1997 and 2007, while at the same time services share increased for 3,3\% (Marjanović, Bošković, 2010, p. 96). Admittance of new member states in the Union has brought new challenges to the industrial policy, such as coordination of different industrial systems, which were not at the same level. Despite all this, the European Union continued with incentives for manufacturing sector and industrial policy, emphasizing its significance for higher employment rate, industrial growth through continuous innovation and sustainable development, higher living standard and overall social integration based on knowledge and information.

The analysis of global economic leaders' results has shown that the USA, Japan and some other Asian countries, based on modern high-tech industry,

\footnotetext{
${ }^{2}$ Main goal, to make European economy leader on global market, based on knowledge, human resource key competenece, sustainable development and social cohesion till 2010, seemed less achievable. Among other things, it was a conclusion of a High Level Group for analysis of the Lisbon Strategy implementation (The Kok Report), formed by the EU in 2004 and chaired by ex Dutch Prime Minister Vim Kok (Report from the High Level Group chaired by Wim Kok, 2004). Lisbon Strategy failure was primarily caused by loosely defined goals and contradictory priorities, which led to 2005 European Council revision of Lisbon Strategy, diverting EU priorities to growth and employment.
} 
have more success on the global market than European countries. This is due to higher productivity, achieved through continuous use of new technology developments (primarily the Internet). Hence, with the Lisbon Strategy the EU insisted on further industry development, with industrial policy based on research and innovation, continuous development of information and communication technology and human resource investment, their constant education and training, in accordance with latest technology of modern business. In order to achieve such ambitious goals set by this strategy (in the first place, a plan to make the EU economy the most productive and most dynamic global economy based on knowledge till 2010), the Union continued with its industrial policy idea to maintain the manufacturing sector key role in economic growth, even in a high-tech society, with emphasis on services (Commission of the European Communities, 2002). At this point, however, its further development had to be in compliance with social and environmental aspects, which meant industrial policy had to coordinate its further industry growth and development with sustainable developments principles and gudelines.

Although some EU member states have a long tradition in research and innovation, effects of their research have often remained unused within the Union. Reason for this is the fact that a large part of it was carried out through national or regional research program, which was, at the same time, the area of their implementation, without broad use on the Union market (according to innovation parameters, only Sweden, Switzerland and Finland are ahead of Japan and USA). These problems initiated Lisbon Strategy revision in several occasions, and revisions from 2005 and 2008 made significant progress in this area, on the Union level as well as some member states. This encouraged EU institutions to prioritize further investment in knowledge and innovation, free competition and business potential (especially small and medium-sized companies), higher flexibility and faster adaptability on human resource market and better inclusion in climate change and energy issues, in the Lisbon Agenda of 2008-2010 (EU Law and Publications, Eur-lex, 2007).

However, this period was marked by global recession, which started in 2008, severely affecting the European Union as well. It added more trouble to accumulated problems in the EU functioning and the whole situation resulted in significant losses in European economy, especially for Southern and Eastern European countries. By 2010 it became clear that the Union needed a new strategy for overcoming the crisis. The new strategy was Europe 2020 and it was suggested by European Commission, in March 2010 (European Commission, 2010). 
The Role of "Europe 2020" Project in the European Union's Competitiveness on the Global Market

Europe 2020 is a ten-year development strategy, suggested and created by the European Commission, adopted on European Summit on June 17th 2010.

Project Europe 2020 is a follow-up of Lisbon Strategy, which failed to achieve scheduled goals of EU growth and development in the first decade of the new millennium. Basis of the new Europe 2020 strategy is a realization of smart, sustainable, inclusive growth and development, with higher coordination of national policies and supranational Union policy (European Commission, 2010). "In the EU industry competitiveness improvement, key role is intended to knowledge, innovation and entrepreneurship... Dynamic and competitive industry is a widest foundation for efficient achievement of social, environmental and economic goals of the EU" (Savić, 2013, p. 230).

The main goals of this strategy, especially important for the EU industrial policy area, refer to industry growth increase, higher investment in research and developmet of high-tech innovation (3\% of GDP, which is still significantly less than USA and Japan). However, this growth and development has to be in compliance with sustainable development principles - one of the main priorities in the EU development strategy is a reduction of greenhouse gas emission for at least $20 \%$, increase of renewable energy share in total energy consumption for the same percentage, as well as increasing energy efficiency. Also, industry development must provide increase in the employment rate from $69 \%$ to $75 \%$, especially among population between 20 and 64 years, with continuous education and modernization of human resources in order to increase competitiveness of this factor of production (European Council, 2010). However, Europeans are far from monolithic in their preferences. It was just not possible, with all the different cultures, nations and heritage that they brought. Many authors believe that the plan to make Europe the most dynamic and competitive economy in the world failed, because lots of Europeans do not want to live in the most dynamic and competitive economy in the world. They want long holidays, restrictive labour laws, generous welfare states and 35 hour weeks (Charlemagne, The Economist, 2010). This is particularly the case in traditionally hedonistic oriented Mediterranean countries which have most problems, at least statistically speaking. ${ }^{3}$ Examples like this one show why the

\footnotetext{
${ }^{3}$ According to information of numerous real estate agencies in Europe, Western Europeans and Scandinavians have bought thousands of houses and apartments in Spain in the last ten years. Reason for this is very simple - Spain has over 300 sunny days a year, beautiful islands and cities on the coast, and all of this pretty much resembles to a perfect life. The other side of this perfect life is unemployment rate which exceeds $30 \%$ and collapse of the banking system, due to inability of a large number of people to pay off their housing loans. Sounds impossible, but it is actually true - a 4 bedroom apartment in Valencia, $115 \mathrm{~m} 2$, now costs 25.000 eur (http://www.rightmove.co.uk/overseas-property/property-46814231.html, June 15th 2014)
} 
European Union struggles, ever since the beginning, to carry out its plans and strategies. ${ }^{4}$ In hyper dynamic tendencies of modern business on European and global market, it is hard to imagine a strategy which will be able to reconcile and integrate different ways of living, value systems, habits and attitudes of different EU residents.

Despite the evident effort of all EU institutions to achieve economically justified smart, sustainable, inclusive growth and development of the Union (with simultaneous integration and coordination of national policies), it is highly unlikely that this will be fully achieved. The EU leaders orientation on Lisbon strategy industrial policy, to target high-tech industry research and development with $3 \%$ of GDP was ambitious. Fact is, however, that only Sweden and Finland met that target, while the EU average remained at 1,84\% of GDP, way behind the USA and Japan. Similar indicators appear in the area of education, which is one of the major problems in the European economy, considering that knowledge and continuous education have been set as the main goals of the EU economic strategy.

Question is, would any strategy in the modern business era, especially after the 2008 recession, set Europe as the world economic leader on the global market. Since the beginning of a new millennium, more and more different parameters and research results indicate a supersaturation of the global market and severe stagnation of the most powerful economies worldwide. For some it might be a surprise, for others a logical sequence of cyclic events on the global level, but there are many predictions about Africa being the only continent with economic growth potential in the next ten years. North America, Europe, Australia, Japan, have already reached their peak, not only in terms of economy, but also in political, social, and cultural sense, therefore it is quite understandable that the only remaining countries able for growth and development are the ones far behind the most developed countries of global economy. A large number of world's biggest corporations from most developed countries are outsourcing in African countries in the last few years, to achieve significantly lower production costs, especially workforce costs, basing their business on traditional industry. At first glance, the data looks almost unbelievable: (1) Ethiopian economy grows ten times faster than economy in Great Britain in the last decade, and this growth is based on high-tech transformation of agriculture and on services; (2) Mozambique has annual

\footnotetext{
${ }^{4}$ Because it is simply not possible in a long run, to have the same brand of espresso coffee cup, which costs 1 euro in downtown Munich and 4 euros in a small seaside village beach bar in Greece. This is trivial and simplified example, but in the backgroung of such examples one can discover the essence of the EU existential problems. It has become obvious that ten year development plans, created by bureaucratic committees which often have no tangents with real economy that is going on in factories, corporations, markets, restaurants, small and medium companies, are doomed to fail from the start.
} 
growth of over $7 \%$ ten years in a row now, which makes it one of the countries with the highest growth in the world. A particularly significant fact is that this growth is being achieved in almost every sector of economy, from heavy industry and mineral exportation (mostly coal), to intense development of financial services, transport, communication and construction; (3) Tanzania smoothly bypassed global recession, basing its economy on the stocks of gold exportation of this natural resource enabled intense development of industry, services and construction, causing a 7\% annual growth in this country for years; (4) Ghana made an incredible $9 \%$ growth in 2012, same as China, thanks to revenues from oil, gold and coconut export and a 6\% services growth; (5) Because of its oil reserves, Nigeria became a serious competitor on the global market, and a long-term stable economic growth of 7,5\% is being achieved through development of telecommunication, construction, industry and agriculture, wholesale and retail, hotel and catering services (Jackson, 2012). Table 1 shows world's ten fastest growing economies since the beginning of the millennium, with projection till 2015.

Table 1. World's Ten Fastest Growing Economies, 2001 - 2015

\begin{tabular}{|c|c|c|c|}
\hline \multicolumn{4}{|c|}{ World's ten fastest growing economies according to annual average GDP growth, $\%$ ) } \\
\hline \multicolumn{2}{|c|}{$2001-2010$} & \multicolumn{2}{|c|}{$2011-2015$} \\
\hline Angola & 11.1 & China & 9.5 \\
\hline China & 10.5 & India & 8.2 \\
\hline Myanmar & 10.3 & Ethiopia & 8.1 \\
\hline Nigeria & 8.9 & Mozambique & 7.7 \\
\hline Ethiopia & 8.4 & Tanzania & 7.2 \\
\hline Kazakhstan & 8.2 & Vietnam & 7.2 \\
\hline Chad & 7.9 & Congo & 7.0 \\
\hline Mozambique & 7.9 & Ghana & 7.0 \\
\hline Cambodia & 7.7 & Zambia & 6.9 \\
\hline Rwanda & 7.6 & Nigeria & 6.8 \\
\hline
\end{tabular}

Source: Economist online

As it can be seen from Table 1, not only there are no European countries in world's ten fastest growing economies, (Kazakhstan is largely Asian country, with small part of its territory on the European continent), but there are mostly African and some Asian countries on the list. Why is this African and Asian growth and development so important for European Union and what kind of relation can be established here? It is important because it brings us back to the question if the most powerful and developed world countries have reached the peak of their economies and how to achieve further growth on oversaturated 
global market. This question goes beyond the scope of economics, taking a social and existential dimension - has the modern consumer society reached its final limits, both in terms of production, but also in terms of consumption? No doubt that the industry has repeatedly altered and improved the quality of human life with its accomplishments. These changes and improvements have been most obvious in the past few decades, with intense development of information and communication technologies, irrevocably changing our lives and the world we live in. One of the most important issues regarding further growth and survival of this world and all of us is how to conceive industrial policy and its future strategic foundation, to make the future possible at all.

\section{Conclusion}

Power relations in global economy were established during mid-twentieth century, when the USA and Japan seized the most profitable segments of the global market, keeping it to the present. What should have been the biggest strength of the EU economy through its integration, unification and increased number of members, turned out to be one of its greatest weaknesses. Irreconcilable differences in culture, habits, level of development and work ethics between North and West Europe on one side, and South and East Europe on the other, have brought confusion, failure and inability to implement any strategy of industrial and overall economic growth within the EU. Creators and leaders of the biggest industrial revolution so far, in the field of information and communication technologies, are still the USA, Japan, but also some highly developed Asian countries, while the most developed European countries mainly follow their development and achievements.

Mediterranean countries facing bankruptcy, Ukrainian crisis, possible referendums in some countries regarding their leaving the EU, as well as demands for secession all over Europe, are some of the problems in the biggest EU crisis, since its establishment. On the other hand, considering intense competition of modern business, rest of the world will without a doubt use their chances for entering global market and strengthening positions on it. Because of all this, Europe urgently needs sustainable development strategy with compatible industrial policy - a factor which would probably solve a large part of its accumulated problems, getting Europe back in the game with biggest global players. 


\section{References}

Charlemagne (2010) „Do Europeans want a dynamic economy?“, The Economist, European Politics, January http://www.economist.com/blogs/charlemagne/2010 /01/do_europeans_want_dynamic_economy, pristupljeno 15. juna 2014. godine

Commission of the European Communities (2002) Communication from the Commission to the Council, The European Parliament, The Economic and Social Committee and The Committee of The Regions, Industrial Policy in an Enlarged Europe. Brussels, Com 714, Final, p. 7, http://ec.europa.eu/invest-in research/pdf/download_en/ industrial_policy_enlarged_europe.pdf, 12.06. 2014

Commission of the European Communities (2002) Communication from the Commission, Providing New Momentum, Strenghtening - Reorienting - Opening up new perspectives Commission of the European Communities The European Research Area. Brussels, COM, 565 Final, http://old.certh.gr/libfiles/PDF/MOBIL -11-com2002_0565en01.pdf, pristupljeno 12. 062014

Cornet, S., (2009) „The 1960's European Golden Age“, Ashford University, Twentieth Century Europe - HIS 306 ,http://www.sunstar-solutions.com/60sEurope.htm, pristupljeno 6. 06. 2014

Coucil of the European Union, (2005) The Economic Costs of Non-Lisbon, A survey of the literature on the economic impact of Lisbon-type reforms, Comission Staff Working Document, Commission of the European Communities, Brussels 2005. SEC 385, http://www.consilium.europa.eu/uedocs/cms_data/docs/pressdata/en/ misc/84257.pdf pristupljeno 13. 06. 2014

Devine, P., Katsoulacos Y., and Sugden R., (1996) "Competitiveness, subsidiarity and industrial policy”, Routledge London, England, 62

Economist online, Januar $6^{\text {th }} 2011$., Africa's impressive growth, http://www.economist.com /blogs/dailychart/2011/01/daily_chart, 15. 06. 2014

Eichengreen, B., (2006) „The European Economy since 1945: Coordinated Capitalism and Beyond", Princeton University Press, http://pup.princeton.edu/chapters/ s8253.html, pristupljeno 9. 06. 2014

European Council, (2010) „Council Conclusions“, Brussels, http://www.consilium. europa.eu/ueDocs/cms_Data/docs/pressData/en/ec/115346.pdf, 14. 06. 2014

European Commission, Europe 2020: Commission proposes new economic strategy 03.03.2010., http://ec.europa.eu/news/economy/100303_en.htm, 14. 06. 2014

EU Law and Publications, Eur-lex, "Proposal for a Community Lisbon Programme 2008 2010”, COM(2007) 804 final (2007), European Commission, Brussels, http://eurlex.europa.eu/legal-content/EN/TXT/?uri=CELEX:52007DC0804, 13. 06. 2014

Europa, Summaries of EU Legislation, (2010) Treaty of Maastricht on European Union, http://europa.eu/legislation_summaries/institutional_affairs/treaties/treaties_maast richt_en.htm, pristupljeno 10.06. 2014

European Union, How the EU works, (2014) The Schuman Declaration, 9. May 1950., http://europa.eu/about-eu/basic-information/symbols/europe-day/schumandeclaration/index_en.htm, pristupljeno 5. 06. 2014 
European Union, How the EU works, (2013) http://europa.eu/about-eu/basicinformation/index_en.htm, pristupljeno 3.06. 2014

Gales, Kander, Malanima and Rubio, (2007) "North versus South: Energy transition and energy intensity in Europe over 200 years", European Review of Economic History, 230-232

Ivan-Ungureanu, C., Marcu, M., (2006) "The Lisbon Strategy", Romanian Journal of Ecomonic Forecasting 1/2006, http://www.ipe.ro/rjef/rjef1_06/rjef1_06_6.pdf, pristupljeno 11.06. 2014

Jackson, T., (2012) „The Seven Fastest Growing Economies In Africa“, Ventures, http://www.ventures-africa.com/2012/08/the-7-fastest-growing-economies-inafrica/, pristupljeno 15. 06. 2014

Marjanović, V. i Bošković, G. (2010) "Evropski inegracioni procesi i strukturno prilagođavanje“, Regionalni razvoj i demografski tokovi zemalja jugoistočne Evrope, međunarodni naučni skup, Niš: Ekonomski fakultet, 91-103.

Report from the High Level Group chaired by Wim Kok, 2004., http://ec.europa.eu/research/evaluations/pdf/archive/fp6-evidencebase/evaluation_studies_and_reports/evaluation_studies_and_reports_2004/the_li sbon_strategy_for_growth_and_employment_report_from_the_high_level_grou p.pdf, pristupljeno sajtu 11.06. 2014

Rightmove Overseas, (2014) http://www.rightmove.co.uk/overseas-property/property46814231.html, pristupljeno 15. 06. 2014

Savić, Lj. (2013) „Ekonomika industrije“, Beograd: Centar za izdavačku delatnost.

Sauter, W., (1997) "Competition Law and Industrial policy in the EU”, Clarendon Press, Oxford, UK, 75-79

Vajdenfeld, V. i Vesels, V. (2003) „Evropa od A do $\check{S}$ - Priručnik za evropsku integraciju“, Beograd: Fondacija Konrad Adenauer.

Yergin, D., (2008) „The Prize: The Epic Quest for Oil, Money and Power“, New York: Simon and Schuster. 


\title{
INDUSTRIJSKA POLITIKA KAO FAKTOR KONKURENTNOSTI EVROPSKE UNIJE NA GLOBALNOM TRŽIŠTU
}

\begin{abstract}
Apstrakt: Ujedinjenje najrazvijenijih evropskih država i njihovih ekonomija baziranih na teškoj industriji, nakon Drugog svetskog rata, izgledalo je kao jedino rešenje da se evropsko tržište odupre zahuktalim privredama SAD i Japana, odnosno da tim privredama postane konkurent na globalnom tržištu. To je ostvareno kroz različite oblike ekonomskih zajednica, formiranih na teritoriji Evrope tokom druge polovine dvadesetog veka, a koje su 1992. godine sporazumom u Mastrihtu, preimenovane u Evropsku uniju. Industrijska politika Evropske unije je od svog nastanka imala iste prioritete - da, na bazi investicija u znanje i visokotehnološke inovacije, Evropa postane lider globalne ekonomije. To se, međutim, još uvek nije desilo, a s obzirom na razne ekonomsko-političke krize koje poslednjih godina potresaju Uniju, šanse da će se desiti su sve manje. Razlozi za takvo stanje su brojni, kako unutar same Unije, tako i van nje. Implicitno se postavlja pitanje da li su najrazvijenije zemlje u svetu i njihove ekonomije dostigle svoj zenit i kako Evropska unija može postići dalji rast na prezasićenom globalnom tržištu. U radu se razmatra uloga industrijske politike kao faktora koji je doprinosio i koji u budućnosti još više može doprineti da se reše mnogi nagomilani problemi u Evropskoj uniji, čime bi ova ekonomsko-politička zajednica evropskih država postala konkurentnija na globalnom tržištu.
\end{abstract}

Ključne reči: industrijska politika, Evropska unija, konkurentnost, globalno tržište, ekonomsko-političke krize 